\title{
THE PLACENTAL TRANSFUSION SYNDROME IN MONOZYGOUS TWINS*
}

\author{
BY \\ G. CORNEY and W. AHERNE \\ From the Departments of Paediatrics and Pathology, United Oxford Hospitals
}

(RECEIVED FOR PUBLICATION JULY 6, 1964)

The description in Genesis of the birth of Esau and Jacob records that 'the first came out red'; this may well have been the first description of the birth of a plethoric twin.

It was realized towards the end of the last century that there could be a difference in the haemoglobin values in uniovular twins (Westphalen, 1897, quoted by Price, 1950); a little earlier Schatz (1882 and 1884-1910, quoted by Newman, 1923) had demonstrated communications between the two halves of a monochorionic placenta, but 50 years passed before the syndrome in which one twin is born anaemic, the other polycythaemic, was attributed to such vascular anastomoses (Herlitz, 1941).

A number of cases of the 'placental transfusion syndrome' have now been described, and in this paper the published reports will be reviewed; one further case is described, being of particular interest as the anaemic baby had purpura and thrombocytopenia at birth, and has since been found to have several abnormalities.

\section{Case History}

The mother, a Rhesus positive multigravida aged 39 years, was quite well in the early months of her pregnancy; when seen in the antenatal clinic at the 34th week a diagnosis of twins was made, and, as ankle oedema was present, she was admitted to the Churchill Hospital for rest. Her condition improved sufficiently to allow discharge home two weeks later; she was readmitted two weeks before term in labour.

Five hours after the onset of labour the first twin was delivered as a breech; he was pale and limp, but gasped at once, and regular respirations were established within three minutes. Petechiae were noted at birth and quickly became more marked. The second baby was delivered spontaneously ten minutes later and cried well immediately; he was very red in contrast to the pallor of his twin (Fig. 1).

On examination, Twin I, birth weight $4 \mathrm{lb}$. (1.8 kg.),

\footnotetext{
* A paper read at a meeting of the Royal Society of Medicine, Section
} of Paediatrics, in Oxford, June 1964. was a pale quiet baby $(\mathrm{Hb} 39 \% ; 5 \cdot 8 \mathrm{~g} . / 100 \mathrm{ml}$ ); petechiae and ecchymoses were present mainly on the face, but also, though to a lesser extent, on the trunk. The liver and spleen were easily palpable, and a systolic murnur could be heard over the whole praecordium, which was maximal in the third and fourth intercostal spaces at the sternal border. The clinical picture was very similar to that seen in a baby with severe anaemia due to haemolytic disease of the newborn. Twin II, birth weight $5 \mathrm{lb} .1 \mathrm{oz}$.

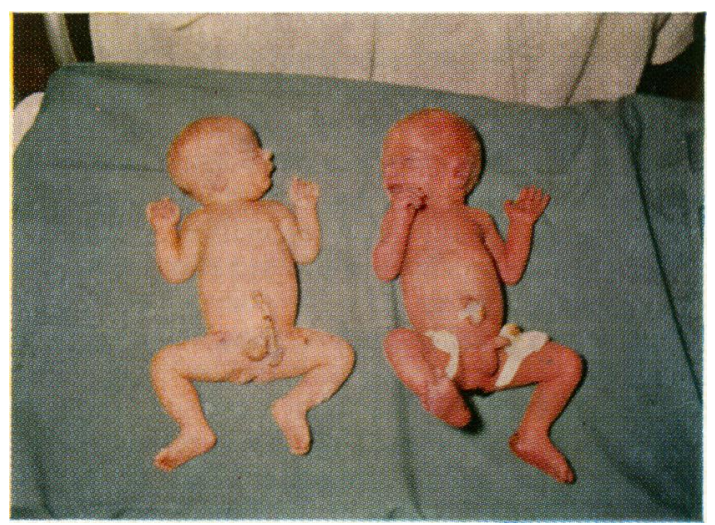

Fig. 1.-Appearance of the twins at birth. Twin $I$ is on the left and Twin II on the right.

$(2.3 \mathrm{~kg}$.$) , was in excellent condition, with a striking$ plethoric appearance $(\mathrm{Hb} 170 \% ; 25 \cdot 2 \mathrm{~g} . / 100 \mathrm{ml}$.); the liver and spleen were easily palpable.

Apart from the extreme difference in the haemoglobin values, the main features in the investigations were the thrombocytopenia and marked normoblastaemia seen in the blood film of Twin I; a further unusual feature of this film was the almost complete absence of lymphocytes which were plentiful in his twin. A full account of the investigations is given in Table 1 and Table 2.

The Placenta. The placenta was monochorionic with two amniotic sacs. The two portions were strikingly dissimilar (Fig. 2), that belonging to Twin I being large, 
TABLe 1

BLOOD AND URINE FINDINGS IN TWINS AND MOTHER

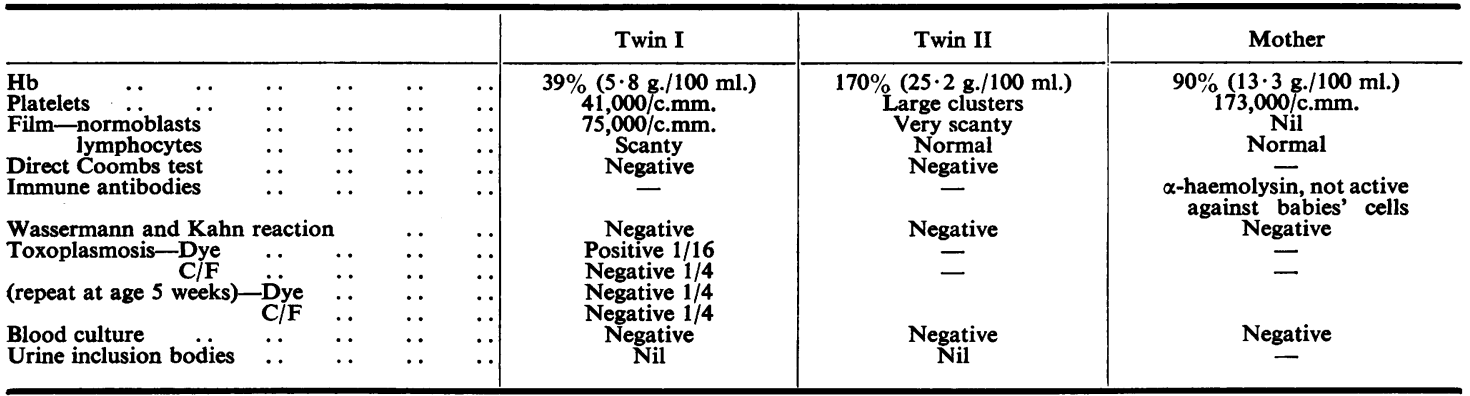

TABLE 2

BLOOD GROUP OF THE TWINS AND THEIR PARENTS

\begin{tabular}{|c|c|c|c|c|c|c|c|c|c|c|c|c|c|c|c|}
\hline & & & ABO & MNS & $\mathbf{P}_{1}$ & $\mathbf{R h}$ & $\mathbf{L u}^{\mathbf{a}}$ & $\mathbf{K}$ & Lea & Leb & Fya & Fyb & $\mathbf{J k}^{\mathbf{a}}$ & $\mathbf{J k b}$ & $\mathbf{X g}_{\mathbf{g}^{\mathbf{a}}}$ \\
\hline $\begin{array}{l}\text { Twin II } \\
\text { Twin I } \\
\text { Father } \\
\text { Mother }\end{array}$ & 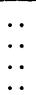 & $\begin{array}{l}\ldots \\
\cdots \\
\ldots\end{array}$ & $\begin{array}{l}\mathbf{A}_{1} \\
\mathbf{A}_{1} \\
\mathbf{A}_{1} \\
\mathbf{O}\end{array}$ & $\begin{array}{l}\text { MNSs } \\
\text { MNSs } \\
\text { NsNs } \\
\text { MMS }\end{array}$ & $\begin{array}{l}+w \\
+w \\
+ \\
-\end{array}$ & $\begin{array}{cc}\mathbf{R}_{\mathbf{1}} & \mathbf{R}_{\mathbf{2}} \\
\mathbf{R}_{\mathbf{1}} & \mathbf{R}_{\mathbf{2}} \\
\mathbf{R}_{\mathbf{1}} & \mathbf{R}_{\mathbf{1}} \\
\mathbf{R}_{\mathbf{2}} \mathbf{r}\end{array}$ & $\begin{array}{l}- \\
- \\
-\end{array}$ & $\begin{array}{l}\overline{-} \\
\overline{-}\end{array}$ & $\begin{array}{l}+ \\
+ \\
+\end{array}$ & $\overline{-}$ & $\begin{array}{l}- \\
\overline{+} \\
+\end{array}$ & $\begin{array}{l}+ \\
+ \\
+ \\
+\end{array}$ & $\begin{array}{l}+ \\
+ \\
+ \\
+\end{array}$ & $\begin{array}{l}+ \\
+ \\
+ \\
+\end{array}$ & $\begin{array}{l}+ \\
+ \\
+ \\
+\end{array}$ \\
\hline
\end{tabular}

pale, and thick, and weighing $678 \mathrm{~g}$.; and that belonging to his twin being small and deeply congested, weighing only $254 \mathrm{~g}$. The two portions were sharply demarcated except at the centre where there appeared to be one or more shared cotyledons. The superficial vessels of the large pale portion were of fine calibre and contained little blood (Fig. 3); the cord, which was marginally inserted, was rather thin (diameter about $0.75 \mathrm{~cm}$.). The vessels of the other half, by contrast, were grossly engorged and tortuous; the cord on this side was thicker (diameter 1.0 $\mathrm{cm}$.) and the insertion was velamentous. Several small anastomoses were visible crossing in the subamniotic tissues from one vascular territory to another. These connected veins to veins. No arteriovenous or other anastomoses were found amongst the superficial vessels.

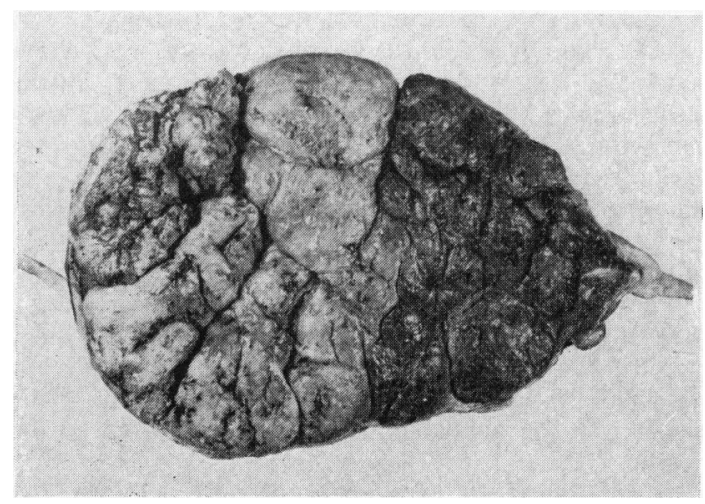

FIG. 2.-Maternal surface of placenta, showing the sharp demarcation into unequal contrasting portions.
Microscopical Features. The monochorionic structure of the placenta was confirmed. The chorionic villi of the large pale portion were bulky, with prominent trophoblast, frequent Hof bauer cells, and marginated capillaries containing a high proportion of nucleated red cell precursors (Fig. 4). The resemblance to a placenta in severe haemolytic disease was close. The volume of the villous tissue was estimated as $356 \mathrm{ml}$.; the volume of the intervillous space as $239 \mathrm{ml}$.; and the total villous surface area as $9.8 \mathrm{sq} . \mathrm{m}$. (These quantitative estimates were made by techniques that will be described by Aherne and Dunnill (in the press.) The small portion of the placenta was histologically normal and mature, but the capillaries were intensely congested; the visible blood was noticeably free from nucleated red cell precursors

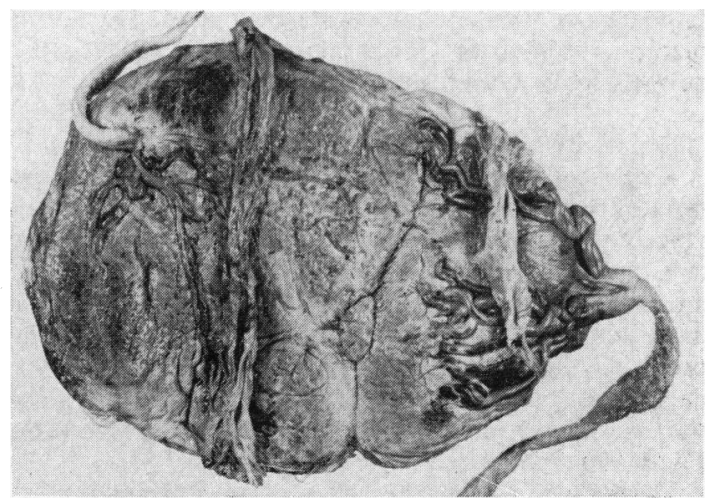

FIG. 3.-Foetal surface of placenta, with amnions peeled back. Note very small size of surface anastomoses between the two vascular systems. 


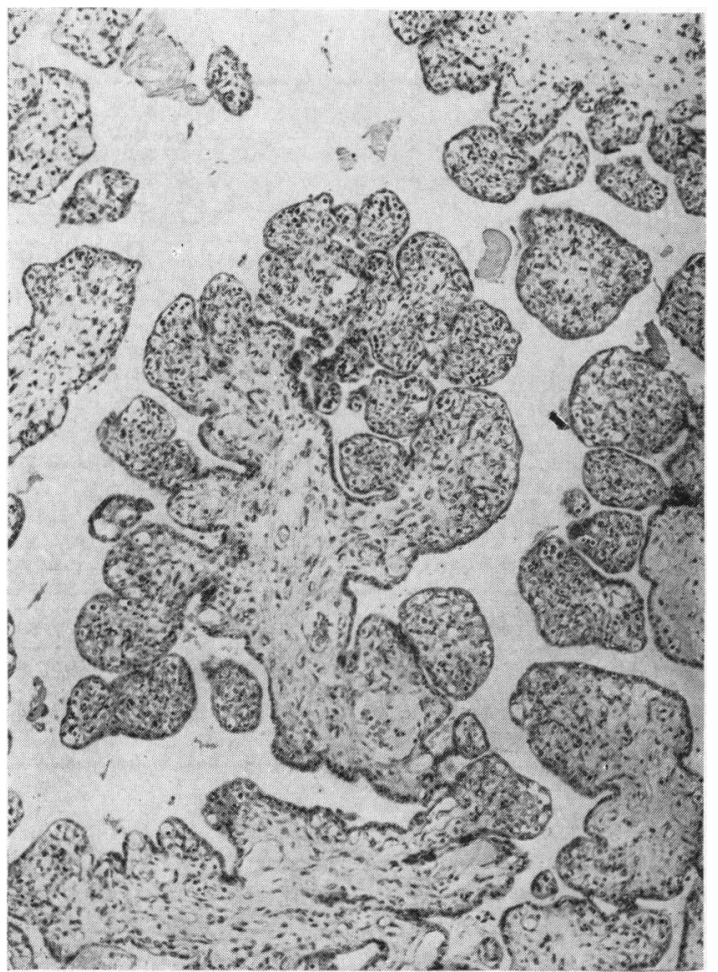

FIG. 4.-Typical villi and villous stem from the larger, pale portion of the placenta. Note the bulbous villi, with marginated capillaries full of nucleated red-cell precursors. (H. and E. $\times 90$.)

(Fig. 5). The volume of the villous tissue in this portion was estimated as $113 \mathrm{ml}$; the volume of the intervillous space as $73 \mathrm{ml}$.; and the total villous surface area as 4.9 sq. m.

These estimates of surface area (Twin I: $9 \cdot 8$ sq. m.; Twin II : $4 \cdot 9$ sq. m.) may be compared with the following estimates of mean villous surface area in five normal placentas at 38-40 weeks' gestation: $12 \cdot 6,11 \cdot 6,10 \cdot 6,10 \cdot 5$, and $9 \cdot 1$ sq. $m$. (Aherne and Dunnill).

Treatment and Progress. Twin I initially developed signs of respiratory distress; in view of the severe anaemia and the possibility of haemolytic disease (which was considered at that early stage), it was decided to perform an exchange transfusion. On completion of this, his condition was slightly improved, and the systolic murmur previously noted was no longer audible. The following day, as the haemoglobin was still only $51 \%(7 \cdot 5 \mathrm{~g} . / 100$ $\mathrm{ml}$.), a simple transfusion of blood $(60 \mathrm{ml}$.) was given. The platelet count remained low.

During the first four days his condition was poor; there were recurrent cyanotic attacks with occasional twitching and jerky movements; crepitations were present in both lungs and on several occasions fresh blood was aspirated

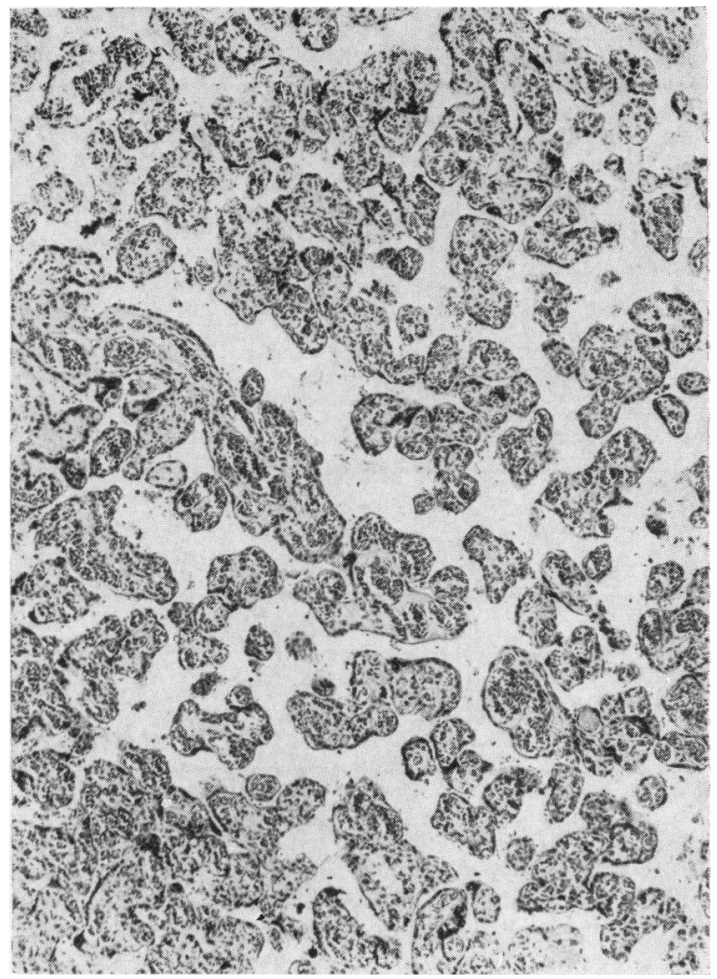

FIG. 5.-Typical villi from smaller portion of placenta. Though the capillaries are deeply engorged the general morphology is normal. (H. and E. $\times$ 90.)

from the pharynx and stomach. Digoxin was given, together with a course of tetracycline; sedation with phenobarbitone was used as necessary. Slight jaundice developed, the maximum bilirubin being $5 \mathrm{mg} . / 100 \mathrm{ml}$. From the fifth day of life, however, there was a steady improvement. The petechiae faded, but the size of the liver and spleen remained essentially unchanged. The systolic murmur previously heard was again heard at this stage, but this gradually became less marked. By the third week of life the platelet count had risen to $215,000 /$ c.mm. and remained at a normal level. Digoxin was discontinued from the fourth week without ill effect. By the sixth week, however, the haemoglobin had fallen to the low level seen at birth-37\% $(5 \cdot 5 \mathrm{~g} . / 100 \mathrm{ml}$.), and a third transfusion was, therefore, given.

On discharge from the premature nursery at age 2 months his general condition was very good; a soft systolic murmur could still be heard, the liver and spleen were still easily palpable. Oral iron, which had been given from the age of 1 month, was continued on discharge.

Twin II was in excellent condition at birth, and remained so, apart from very slight jaundice (maximum bilirubin $4 \mathrm{mg} . / 100 \mathrm{ml}$.); no treatment was given to this baby. On discharge at the age of 3 weeks the liver and 
spleen were palpable, but clinical examination was otherwise normal.

Further Progress. When seen for review at the age of 4 months, each twin could lift his head from the pillow and both would follow a moving light; the mother felt, however, that Twin II was brighter and more responsive than his brother; he certainly pulled to sitting in a more satisfactory manner and maintained a better posture in this position. Twin I's haemoglobin was again low despite treatment with oral iron.

Shortly after this review Twin I was noticed (by his mother) to have abnormal eye movements, and at the age of 5 months was found to have bilateral lamellar cataracts. It was also apparent that his hearing was less good than that of his twin, and Mr. Gavin Livingstone found that there was impairment of hearing in both ears which was more marked on the left side. Discission operations were performed on the left eye at the age of 11 months by Dr. Sarwar at the Oxford Eye Hospital, the appearance of the fundus was normal; a similar operation is planned for the other eye.

Both twins were seen for review at age 1 year when it was apparent there was a marked difference in development. Twin I weighed $19 \mathrm{lb} .15 \mathrm{oz}$. (9 kg.), made no attempt to sit, and head lag was still present when he was pulled to the sitting position; he would sit with support, but not well. He was able to follow a moving light, and was obviously able to see the movement of his hands. There was no evidence of congenital heart disease. The teeth were stained yellow, probably due to the tetracycline which had been given in the first week of life. His development was that of a 3-to-4-month-old baby.

Haemoglobin, white cell and platelet counts, urine (including amino acid chromatography), and electrocardiogram were all within normal limits. A radiograph of hand and wrist for bone-age showed identical development with that of his twin.

In marked contrast, Twin II, weight $22 \mathrm{lb} .11 \mathrm{oz}$. $(10.3 \mathrm{~kg}$.$) , was in all respects a normal little boy who$ laughed and chuckled, crawled, pulled to standing, and used his hands and fingers quite well. There was no evidence of cataract, and vision and hearing seemed normal for his age. Investigations, performed as for his twin, were all normal.

\section{Discussion}

At present it is assumed that a monochorionic placenta indicates monozygous twinning (Benirschke, 1961); these twins, however, showed many differences, as has been detailed, and it was decided that the fullest study should be made to determine the zygosity.

The twins were of the same sex; 10 blood group systems were studied and found to be identical; and the total finger ridge counts were similar. It was calculated that according to the table of Maynard Smith, and Penrose (1954) the total chance of monozygosity was $99 \cdot 6 \%$.

To complete the investigation it was decided to exchange skin grafts; this was discussed with the parents, who were fully agreeable, and when the twins were 1 year old, Mr. T. J. S. Patterson transferred $1 \mathrm{~cm} .{ }^{2}$ Wolfe Grafts (full thickness of skin) from the inner side of the upper arm; both homografts and autografts were exchanged. It is not thought that this procedure has been performed previously when there has been complete knowledge of placentation.

The grafts were inspected at weekly intervals; the initial appearances were those of normal human Wolfe grafts; when seen on the 29th day after grafting, however, there was a difference in the appearance of the homografts. The homograft and autograft on Twin I's arm showed the normal appearances of human grafts at this stage, i.e. a thin layer of desquamated epithelium which could easily be peeled off leaving pink skin beneath. The homograft in Twin II's case showed a thick dark crust; this also stripped off easily leaving a pink but rather irregular surface. All grafts maintained their square shape, and there had been no contracture. Subsequent appearances showed little change.

When human skin grafts are rejected there is evidence of contracture (Rogers, 1957), this was not seen in this case, and it is thought that these grafts had taken and confirmed that the twins were uniovular. The difference in the appearance of the grafts cannot be explained.

It would have been interesting to have exchanged second homografts, for if these had been accepted it would have been decisive evidence of compatibility. 'Such compatibility might be due either to the twins being identical, or, alternatively, if they were nonidentical, to their having become tolerant as a result of interchange of blood during intra-uterine life' (M. F. A. Woodruff, 1964, personal communication).

Extensive blood group studies have been made and there is no evidence of chimaerism. It was not thought justifiable, however, to perform a further grafting procedure. From all the evidence it was concluded that these were monozygous twins.

The clinical state of the first twin, and the microscopical changes in his placenta, would have been compatible with haemolytic disease of the newborn, cytomegalic inclusion body disease, toxoplasmosis, and perhaps syphilis. All these conditions were excluded. It seemed reasonable to suppose that the changes observed were due to transfusion of blood from the first to the second twin through placental anastomoses.

Anastomoses between the vascular territories of the monochorionic twin placenta were suspected as long ago as the late seventeenth century. The first demonstration of their anatomy was given by 
Schatz (1882, 1884-1910) who showed that there were two main types, superficial and deep. The superficial anastomoses, he found, joined artery to artery or vein to vein (both types can be present in the same placenta) on the foetal surface; the deep connexions were constantly arteriovenous. Schatz drew the important conclusion that the superficial anastomoses compensated for the haemodynamic imbalance set up by the deep ones. Both Schatz, and more recently Benirschke (1961), stress that superficial anastomoses are present in the great majority of monochorionic twin placentas, and that it is the absence (or inadequacy) of these communications that may harm the foetus. Anastomoses as found by Benirschke in 60 monochorionic placentas are given in Table 3.

\section{TABLE 3*}

VASCULAR ANASTOMOSES IN 60 MONOCHORIONIC PLACENTAS (BENIRSCHKE, 1961)

\begin{tabular}{|c|c|c|c|c|}
\hline \multirow{2}{*}{\multicolumn{3}{|c|}{ Anastomosis }} & \multicolumn{2}{|c|}{ Sets of Twins } \\
\hline & & & Total & Survivors \\
\hline $\begin{array}{l}\text { Artery to artery only ... } \\
\text { Artery to artery plus artery to vein } \\
\text { Artery to artery plus vein to vein } \\
\text { Vein to vein only } \quad . . \\
\text { Artery to vein only } \ldots \\
\text { Artery to vein plus vein to artery } \\
\text { Artery to vein plus vein to vein } \\
\text { No anastomoses seen ... }\end{array}$ & $\begin{array}{l}\cdots \\
\cdots \\
\cdots \\
\cdots \\
\cdots \\
\cdots\end{array}$ & \begin{tabular}{l|}
$\cdots$ \\
$\cdots$ \\
$\cdots$ \\
$\cdots$ \\
$\cdots$ \\
$\cdots$ \\
$\cdots$
\end{tabular} & $\begin{array}{r}17 \\
17 \\
2 \\
3 \\
7 \\
2 \\
3 \\
9\end{array}$ & $\begin{array}{r}12 \\
14 \\
2 \\
2 \\
3 \\
1 \\
1 \\
6\end{array}$ \\
\hline
\end{tabular}

* Reproduced by permission of the Editor, New York State Journal of Medicine.

It is agreed that transfusion of blood from one foetus to the other may occur; the time at which this happens and the duration of such a transfusion are in dispute. Bergstedt (1957) and Littlewood (1963) believed that in their cases this happened during delivery. Seip (1956) also held this view, though he differed from Bergstedt in supposing that the dynamics of labour tended to make the second twin plethoric and not the first. In fact, a review of the reported cases shows that the first twin is as likely to be plethoric as the second. Herlitz (1941), following Schatz, thought that there must be a 'slow ooze' from one foetus to the other throughout the pregnancy. The finding of normoblastaemia and reticulocytosis together with enlargement of the liver and spleen would seem to favour this view. It is difficult to explain why the nucleated red cell precursors should be present in only one-half of the placenta, unless (as has been described in the similar syndrome in animals described below) the transfusion had at some point ceased.

Further support for the 'slow ooze' theory comes from quantitative analysis of the placenta in the present case. Normally there is a direct and fairly close correlation between foetal weight and placental villous surface area (Aherne and Dunnili). By analogy with normal infants of comparable maturity, the first twin, attached to a villous surface measuring 9.8 sq. m., might have been expected to weigh at least $6 \mathrm{lb} .10 \mathrm{oz} .(3 \mathrm{~kg}$.). In fact this baby weighed only $4 \mathrm{lb}$. (1.8 kg.). On the other hand the second twin possessing a villous surface of only 4.9 sq. m., grew to a vigorous $5 \mathrm{lb} .1 \mathrm{oz}$. $(2 \cdot 3 \mathrm{~kg}$.) instead of the expected weight of $3 \mathrm{lb} .5 \mathrm{oz} .(1 \cdot 5 \mathrm{~kg}$.) or less. These exceptions to the general rule may be explained by supposing that a prolonged 'slow ooze' from one placenta to the other impoverished the first twin and supplemented the second placenta. This may well have dated from the time of vasculogenesis, as has been previously suggested (Price, 1950).

It must, however, be pointed out that the anaemic baby is not always the smaller twin, as in the cases quoted by Kerr (1959), Valaes and Doxiadis (1960), Littlewood (1963), and Falkner, Datta Banik, and Westland (1962).

Foeto-foetal transfusion may have grave effects, as when acardia is found in one twin, circulation being maintained by his partner. Milder effects are commoner. Benirschke (1958) and Naeye (1963) noted cardiovascular and renal hypertrophy with associated hydramnios in the plethoric twin and converse changes in the anaemic baby. Most attention has been given to the haematological changes already noted and to their clinical concomitants such as hepatosplenomegaly. But thrombocytopenia has not been described previously; Herlitz (1941) in fact reported thrombocythaemia.

Thrombocytopenia has been seen in rubella embryopathy (Berge, Brunnhage, and Nilsson, 1963) and in association with malformations of the limbs (Zetterström and Strindberg, 1958). Platelet formation starts in these early weeks (Fruhling, Rogers, and Jobard, 1949) when the embryo is particularly vulnerable. The association of cataract and impairment of hearing in the anaemic infant is also reminiscent of rubella embryopathy. Since the common causes of these anomalies were excluded, it is tempting to ascribe their occurrence in one of apparently uniovular twins to the abnormal haemodynamics of the milieu in which that twin developed. It must, however, be conceded that the eyes of the anaemic baby were not examined in the neonatal period, and his mother is convinced that he could see in the early weeks. The presence of cataract in the early months, which was not present at birth, has been reported (Ryan, 1956) in a baby who was very anaemic (for reasons undetermined) after delivery and required transfusions.

The placental transfusion syndrome has many features in common with the syndrome of 'parabiotic 
intoxication' (Finerty, 1952) seen in a high percentage of cases when mice or rats are joined by the skin for experimental purposes. If the animals are genetically dissimilar, then the full syndrome with anaemia in the hybrid and polycythaemia in the pure animal is seen; the liver and spleen may enlarge in both and blood pressure changes have been recorded. It has been demonstrated that the anaemia is not due to haemolysis or other mechanisms, and that there is a marked shift of blood from one animal to the other (Tokuda and MacGillivray, 1962.) If the animals are similar genetically, then there is a shift of blood from one to the other, but no other features of 'intoxication'; this has been termed the primary phase (Eichwald, Lustgraaf, Fuson, and Weismann, 1961), in the full syndrome, the secondary phase is thought to be due to immunological mechanisms not possible in animals with an identical genetic background. This would be very like 'runt disease' (Billingham, 1959); in affected babies, however, changes as seen in runt disease have not been found (Naeye, 1963).

The analogy in the case of human monozygous twins would, therefore, seem to be with the primary phase, i.e. a shift of blood due to pressure gradients; a complete analogy is not possible as the animal studies were of necessity performed on mature animals. In the case of the human foetus, if the transfusion does take place in the early weeks, then this will be before the foetus is immunologically competent.

Present theories for the survival of grafts in monozygous twins are based on the presence of placental anastomoses; there have, however, been no previous reports of grafting in twins known to be affected by the placental transfusion syndrome (K. Benirschke, 1964, personal communication). It is of interest that the appearances of the grafts were unusual, though the significance of this is not certain, and it would be difficult to suggest a mechanism for this. It would be instructive to observe the results of grafts in other twins so affected.

The differing progress made by the present pair of twins in the first year of life is striking. Becker and Glass (1963) reported that the polycythaemic twin made better progress up to the age of 4 months, but at 2 years the status of both infants was similar and normal for age. Herlitz (1941) found that the first set of twins he reported still differed in size at 6 years, but were otherwise normal.

The anaemic baby may seem more in need of treatment, but an analysis of deaths shows that the plethoric twin is just as much at risk, being prone to kernikterus, cyanotic attacks, convulsions possibly due to cerebral thrombosis (Chaptal, Jean, Izarn,
Campo, and Menard, 1958), and cardiac failure (Minkowski, 1962).

Neligan and Russell (1954) have suggested that transfusion is indicated if the haemoglobin level falls below $13.3 \mathrm{~g} . / 100 \mathrm{ml}$. in the first 24 hours of life, and stress that the exsanguinated baby may appear deceptively well. Care should be taken not to precipitate cardiac failure, and it was for this reason that we, like others, favoured exchange transfusion initially. Valaes and Doxiadis (1960) used blood from the plethoric baby to restore the haemoglobin level of his twin.

As in haemolytic disease, there appears to be an increased risk of anaemia in the first months of life, even if transfusion has been given initially. It may be that this tendency is only found in infants who have suffered prolonged loss of blood during gestation. In these cases, as in our own case, a further transfusion may be needed, and it seems advisable to give iron therapy for several months.

The plethoric baby may require venesection, followed by an intravenous infusion of saline, glucose-saline, or plasma.

\section{Summary}

Monozygous twins were found to have a gross difference in haemoglobin values at birth, the anaemic baby showing thrombocytopenia; this baby has since been found to be retarded in development, and has cataracts and impaired hearing. Placental vascular anastomoses have been demonstrated, and it is suggested that twin-to-twin transfusion took place from the very early months of the pregnancy.

Skin grafts were performed for the first time in twins affected by this syndrome; these confirmed the fact that the twins were uniovular, but the appearances were somewhat unusual.

Previous case reports are reviewed; comparison is made to a similar syndrome in experimental animals.

We are grateful to Dr. Victoria Smallpeice for permission to publish this report, to Mr. T. J. S. Patterson, Department of Plastic Surgery, United Oxford Hospitals for performing the skin grafts and for his interest in this case, and to Dr. I. B. Shine, Medical Research Council, Population Genetics Research Unit for the genetic studies and help in the preparation of the paper. Blood group studies were performed by Dr. Ruth Sanger at the Lister Institute, London. We would also like to thank Dr. P. A. Davies, Lecturer in Paediatrics, University of Oxford, for her guidance and advice.

\section{REFERENCES}

Aherne, W., and Dunnill, M. S. In preparation.

Becker, A. H., and Glass, H. (1963). Twin-to-twin transfusion syndrome. Amer. J. Dis. Child., 106, 624.

Benirschke, K. (1958). In Gestation. Transactions of the Fifth Conference, ed. C. A. Villee. Josiah Macy Jr. Foundation, New York. 
- (1961). Twin placenta in perinatal mortality. N.Y. St.J. Med., 61, 1499.

Berge, T., Brunnhage, F., and Nilsson, L. R. (1963). Congenital hypoplastic thrombocytopenia in rubella embryopathy. Acta paediat. (Uppsala), 52, 349.

Bergstedt, J. (1957). Monozygotic twins, one with high erythrocyte values and jaundice, the other with anaemia neonatorum and no jaundice. ibid., 46, 201.

Billingham, R. E. (1959). Reactions of grafts against their hosts. Science, 130, 947.

Chaptal, J., Jean, R., Izarn, P., Campo, Mme C., and Menard, P. (1958). La polyglobulie pathologique neo-natale: a propos de cinq observations. Pédiatrie, 13, 515.

Eichwald, E. J., Lustgraaf, E. C., Fuson, R. B., and Weismann, I. (1961). Parabiotic anemia-polycythemia. Proc. Soc. exp. Biol. (N.Y.), 106, 441.

Falkner, F., Datta Banik, N. D., and Westland, D. R. (1962). Intrauterine blood transfer between uniovular twins. Biol. Neonat. (Basel), 4, 52.

Fruhling, L., Rogers, S., and Jobard, P. (1949). L'hématologie normale (tissus et organes hematopoiétiques, sang circulant) de l'embryon, du foetus et du nouveau-né humains. Sang, 20, 313.

Finerty, J. C. (1952). Parabiosis in physiological studies. Physiol. Rev., 32, 277.

Herlitz, G. (1941). Zur Kenntnis der anämischen and polyzytämischen Zustande bei Neugborenen sowie des Icterus gravis neonatorum. Acta paediat. (Uppsala), 29, 211.

Kerr, M. M. (1959). Anaemia and polycythaemia in uniovular twins. Brit. med. J., 1, 902.

Littlewood, J. M. (1963). Polycythaemia and anaemia in newborn monozygotic twin girls. ibid., 1, 857.

Maynard Smith, S., and Penrose, L. S. (1954). Monozygotic and dizygotic twin diagnosis. Ann. hum. Genet., 19, 273.

Minkowski, A. (1962). Le retentissement cardiaque de la polycythémie néo-natale (jumeaux) et post-natale (enfants uniques). Biol. Neonat. (Basel), 4, 61 .
Naeye, R. L. (1963). Human intrauterine parabiotic syndrome and its complications. New Engl. J. Med., 268, 804.

Neligan, G. A., and Russell, J. K. (1954). Blood loss from the foetal circulation: a hazard of lower segment Caesarean section in cases of placenta praevia. J. Obstet. Gynaec. Brit. Emp., 61, 206.

Newman, H. H. (1923). The Physiology of Twinning. University of Chicago Press, Chicago.

Price, B. (1950). Primary biases in twin studies. Amer. J. hum. Genet., 2, 293.

Rogers, B. O. (1957). The genetics of skin homo-transplantation in the human. Ann. N.Y. Acad. Sci., 64, 741.

Ryan, H. (1956). Postnatal cataracts in a premature infant. Amer. J. Ophthal., 41, 310.

Schatz, F. (1882). Eine besondere Art von einseigtiger Polyhydramnie mit anderseitiger Oligohydramnie bei eineiigen $Z$ willingen. Arch. Gynäk., 19, 329.

- (1884-1910). Die Gefässverbindungen der Placentakreisläufe eineiiger Zwillinge, ihre Entwickelung und ihre Folgen. ibid., 24,$337 ; 27,1 ; 29,419 ; 30,169,335 ; 53,144 ; 55,485 ; 58,1$; $60,81,201 ; 92,13$

Seip, M. (1956). A comparison of hemoglobin and erythrocyte values in the first-born and the second-born twin, and in first second, and third triplet during the neonatal period. Acta paediat. (Uppsala), 45, 58.

Tokuda, S., and MacGillivray, M. H. (1962). Parabiotic intoxication, II. The distribution and survival of $\mathrm{Cr}^{51}$-labeled red blood cells. Plast. reconstr. Surg., 29, 462.

Valaes, T., and Doxiadis, S. A. (1960). Intrauterine blood transfer between uniovular twins. Arch. Dis. Childh., 35, 503.

Westphalen, F. (1897). Ueber der mikrochemischen Nachweis von Eisen im fötalen Organismus nebst Beschreibung eines Falles von Schatz'scher Zwillingsschwangerschaft. Arch. Gynäk., 53, 31.

Zetterström, R., and Strindberg, B. (1958). Sporadic congenital spherocytosis associated with congenital hypoplastic thrombocytopenia and malformations. Acta paediat. (Uppsala), 47, 14. 